\title{
Copper and zinc levels in peripheral nerve tissues of rats with experimental carbon- disulphide neuropathy
}

\author{
EDGAR LUKAŠ, PAVEL KOTAS, and IVAN OBRUSNIK \\ Institute of Hygiene and Epidemiology, Prague, Centre of Industrial Hygiene and \\ Occupational Diseases, Prague, Tesla-Research Institute for Communication Engineering, \\ Prague, and Institute of Nuclear Research, Rež, near Prague, Czechoslovakia
}

\begin{abstract}
Lukáš, E., Kotas, P., and Obrusník, I. (1974). British Journal of Industrial Medicine, 31, 288-291. Copper and zinc levels in peripheral nerve tissues of rats with experimental carbon-disulphide neuropathy. By means of neutron activation analysis the levels of zinc and copper in peripheral nerve tissue of two groups of rats with carbon-disulphide neuropathy were estimated. The neuropathy (diagnosed electromyographically) was evoked by inhalation of $3.6 \mathrm{mg} \mathrm{CS} /$ /itre of air (variant 1) or $2.4 \mathrm{mg} \mathrm{CS} /$ /litre of air (variant 2).

Stationary $\mathrm{Zn}$ levels were found in control and exposed animals in both of the experimental variants, while the copper levels increased very significantly from $4.2 \pm 0.3 \mathrm{ppm}$ to $9.9 \pm 1.7$ ppm in experimental variant 1 and from $2.4 \pm 0.3 \mathrm{ppm}$ to $5.6 \pm 0.6 \mathrm{ppm}$ in variant 2 .

The experiments suggest that changes in metal metabolism of peripheral nerve tissue deserve attention as one of the possible pathological links in the development of carbondisulphide intoxication.
\end{abstract}

The production of thiocarbonates (chelating compounds) by the bonding of carbon disulphide $\left(\mathrm{CS}_{2}\right)$ to the amino groups of amino acids and proteins (Mádlo and Souček, 1956; Souček and Mádlo, 1956) aroused the interest of some clinicians and research workers in the elimination of certain metals in the excreta of man and animals, and in the determination of the levels of these metals in different organs as a sign of chronic exposure to carbon disulphide. The results of studies undertaken to investigate these questions were, however, ambiguous.

Djurić, Stojadinović, Bojovic, and Rezman (1968), Asanová (1971), and El-Gazzar, El-Sadik, and Hussein (1973) reported that persons exposed to $\mathrm{CS}_{2}$ excreted raised levels of zinc or copper in the urine. On the other hand, this finding could not be confirmed by Hernberg and Nordman (1969), who studied zinc and manganese excretion in urine in a relatively small group of employees from a chemical $\mathrm{CS}_{2}$ plant.
These questions were investigated experimentally by Scheel (1967), who found lowered copper and raised zinc levels in spinal-cord structures of rabbits exposed to carbon disulphide. In addition, this author demonstrated on the growth curves of these animals a protective effect of a diet whose salt content of copper, zinc, cobalt, manganese, iron, and calcium had been raised by $30 \%$ (by adding the $4 \%$ salt mixture of Phillips and Hart(1935)). Gadaskina and Andreeva (1969) reported raised copper levels in the liver, muscles, and testes of rats exposed to carbon disulphide and at the same time they established enhanced excretion of $\mathrm{Cu}$ and $\mathrm{Zn}$ in the faeces. The level of copper in the brain tissue of their animals did not change.

Apart from these studies and quite independently of the carbon disulphide problem, there appeared a series of papers explaining the development of swayback, a demyelinating disease in sheep, by copper deficiency in the diet (Campbell et al., 1947; 
Campbell, 1963). This work was experimentally verified by Můr, Zăruba, and Charamza (1956), who confirmed that primary damage to the myelin sheath, preceding injury of the axon, developed if copper was blocked in experimental animals by intravenous administration of dithio-diethylcarbamate.

Our own experiments performed in 1968-69 on the development of carbon disulphide neuropathy in rats indicated, though only on a small group of animals and close below the $95 \%$ confidence limit, that a diet supplemented with metal salts afforded a certain protection against the development of peripheral neuropathy (Lukáš, 1970). The copper and zinc doses per rat per day had been raised to $1.1 \mathrm{mg}$ $\mathrm{Cu}$ and $2.4 \mathrm{mg} \mathrm{Zn}$ compared with $0.08 \mathrm{mg} \mathrm{Cu}$ and $0.48 \mathrm{mg} \mathrm{Zn}$ in the standard diet. This stimulated us to investigate also some other indices of the behaviour of copper in the organism, in particular the level of ceruloplasmin activity in the sera of exposed animals. To our surprise it was found that this activity decreased significantly in exposed rats, the decrease depending on the carbon-disulphide dose and the animals' constitution (Kocinová and Lukáš, 1969; Kujalová and Lukáš, 1969; 1970). These two partial results of ours, together with the reports referred to above, induced us to undertake the experiments in the present study.

\section{Material and methods}

Two groups of male SPF rats (mean weight $200 \mathrm{~g}$ ) each containing 36 animals, half the animals of either group serving as controls, were inhalation-exposed to $3.6 \mathrm{mg}$ $\mathrm{CS}_{2} /$ litre of air (variant 1) or to $2.4 \mathrm{mg} \mathrm{CS} /$ litre of air (variant 2) for six hours daily for five days a week. Development of neuropathy was followed with stimulation electromyography by measuring conduction velocity in the motor fibres (MCV) of the lumbar plexus to the tibial nerve (including the neuromuscular transmission) of both hind legs, as described previously (Lukáš, 1970). In both experimental variants the animals were sacrificed when they were overtly affected by advanced neuropathy. This stage was reached after 13 weeks of exposure in experimental variant 1 (decrease of MCV to $56.2 \%$ of normal values) and after as long as $\mathbf{3 7}$ weeks in variant 2 (decrease of MCV to $51.3 \%$ of normal values).

The rats were then killed and, using glass instruments for dissection, both the lumbar and brachial plexuses were excised and the material was processed by the chemical method described by Kotas, Obrusník, Lukáš, and Křivánek (1972). Specimens together with mixed $\mathrm{Zn}$ and $\mathrm{Cu}$ standards were irradiated for 10 hours in a type VVR-S ÚJV reactor, in a neutron-flux equalling $1 \times 10^{13} \mathrm{n}$ $\mathrm{cm}^{-2} \mathrm{~s}^{-1}$. The measurements proper were performed after the chemical separation of the two elements using a semiconductor-(Ge, $\mathrm{Li})$-detector connected with a multichannel gamma-ray spectrometer.

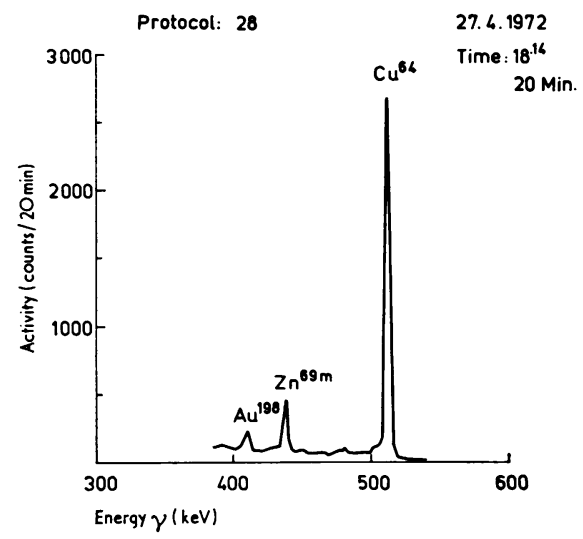

FIG. 1. Gamma-ray spectrum after chemical separation of zinc and copper.

TABLE

Motor Fibre Conduction Velocity in Rats: Lumbar Plexus-Tibial Nerve

\begin{tabular}{|c|c|c|c|c|c|c|}
\hline & \multirow{2}{*}{ Control } & \multirow{2}{*}{$C S_{2}$} & \multicolumn{2}{|c|}{$Z n(p p m)$} & \multicolumn{2}{|c|}{$C u(p p m)$} \\
\hline & & & Control & $C S_{2}$ & Control & $C S_{2}$ \\
\hline \multirow{3}{*}{$\begin{array}{l}\text { Variant } 1 \\
3.6 \mathrm{mg} / 1 . \\
13 \text { weeks' } \\
\text { exposure }\end{array}$} & \multirow{3}{*}{$\begin{array}{c}31 \cdot 1 \mathrm{~m} / \mathrm{sec}^{1} \\
(27 \cdot 6-33 \cdot 2) \\
=100 \%\end{array}$} & \multirow{3}{*}{$\begin{array}{c}17.5 \mathrm{~m} / \mathrm{sec} \\
(16 \cdot 03-18 \cdot 24) \\
=56 \cdot 2 \%\end{array}$} & $\mathrm{n}=17$ & $\mathrm{n}=16$ & $\mathrm{n}=17$ & $\mathrm{n}=16$ \\
\hline & & & $28.8 \pm 4.5$ & $25 \cdot 6 \pm 2 \cdot 0$ & $4.2 \pm 0.3$ & $9 \cdot 9 \pm 1 \cdot 7$ \\
\hline & & & \multicolumn{2}{|c|}{0.6564} & \multicolumn{2}{|c|}{$\begin{array}{l}3.3095^{* *} \\
\mathrm{P}<0.01\end{array}$} \\
\hline \multirow{3}{*}{$\begin{array}{c}\text { Variant } 2 \\
2.4 \mathrm{mg} / 1 . \\
37 \text { weeks' } \\
\text { exposure }\end{array}$} & \multirow{3}{*}{$\begin{array}{c}30 \cdot 8 \mathrm{~m} / \mathrm{sec} \\
(28 \cdot 1-32 \cdot 9) \\
=100 \%\end{array}$} & \multirow{3}{*}{$\begin{array}{c}16 \cdot 3 \mathrm{~m} / \mathrm{sec} \\
(14.8-17 \cdot 7) \\
=51.3 \%\end{array}$} & $\mathrm{n}=11$ & $n=14$ & $\mathrm{n}=11$ & $n=14$ \\
\hline & & & $22 \cdot 3 \pm 4 \cdot 2$ & $23 \cdot 2 \pm 3 \cdot 3$ & $2 \cdot 4 \pm 0.3$ & $5 \cdot 6 \pm 0.6$ \\
\hline & & & \multicolumn{2}{|c|}{0.353} & \multicolumn{2}{|c|}{$\begin{array}{l}9.864^{* * *} \\
P<0.01\end{array}$} \\
\hline
\end{tabular}

${ }^{1}$ Mean values in our first paper (Lukáš, 1970) are $29.9 \pm 0.95 \mathrm{~m} / \mathrm{sec}$ 
The contents of the metals were calculated by comparison with the activities of known amounts of $\mathrm{Zn}$ and $\mathrm{Cu}$ in the standards.

Figure 1 demonstrates a protocol record of a gammaray spectrum obtained after chemical separation of the two metals.

\section{Results}

Seventeen control and 16 experimental animals were taken for the final analysis in experimental variant 1 and 11 and 14 animals respectively in experiment 2 . The Table and Fig. 2 present the absolute figures obtained, in relation to tissue dry weight (ppm), and give a comparison of the relative values, the control values being taken as equal to $100 \%$.

As shown a practically stationary $\mathrm{Zn}$ level was found in control and exposed animals in both of the experimental variants, while the levels of copper increased by $135 \%$ in experiment 1 and by $127 \%$ in experiment 2 . These differences are statistically significant $(P<0.01)$.

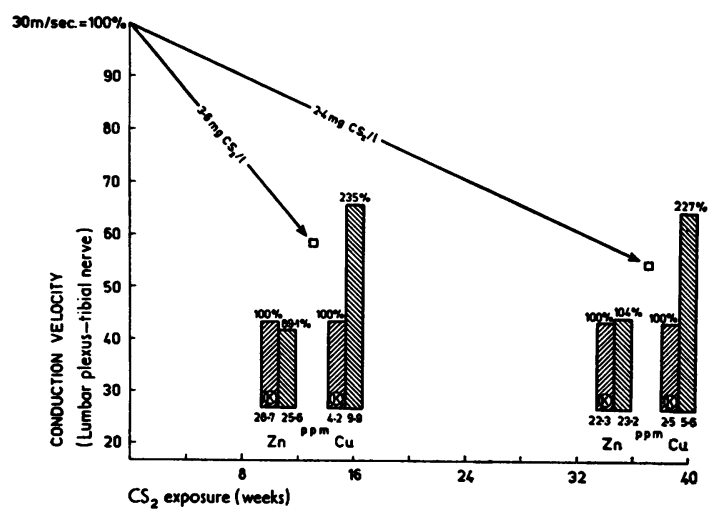

FIG. 2. Conduction velocity in nerve tissue in relation to zinc and copper levels in exposed and control (K) animals.

\section{Discussion}

Comparison of the relative values shows that the shifts are constant and reproducible and that they correlate well with the electromyographic findings in the affected peripheral nerve tissues. A certain advantage in studying the progress of toxic neuropathy is that the presumably primary damage to the myelin sheath will first of all affect the nerve in its ability to transmit impulses, in our case electric stimuli. Thus, if the rate of nerve transmission is measured by electromyography, it is not only possible to detect the damage but, by taking repeated measurements, to follow its progress and to quantify it.

We consider our results to be reliable also for the additional reason that the deviations in $\mathrm{Zn}$ and $\mathrm{Cu}$ levels were obtained under exposure to different concentrations of carbon disulphide fumes but in the presence of approximately equal clinical states, i.e., at a time when in both experiments the rate of conduction velocity in the nerves studied decreased to approximately $51-56 \%$ of the normal values.

An interesting fact is that only the level of copper rose, whereas that of zinc practically did not change as compared with the control groups. We consider that a rôle may have been played here by the higher constant stability of the chelate bond of dithiocarbamates in relation to copper than to zinc, as had already been pointed out by Scheel (1967).

The rise in the copper level after chronic carbondisulphide intoxication suggests in our opinion that the organism, in the present case the peripheral nerve tissue, has as it were a tendency to supplement the bound copper by an additional supply of this metal from reserve sources. However, this hypothesis would require support in the form of knowledge of the amount of chelated (and consequently probably biologically inactivated) copper; but so far we do not know the answer to this question.

The experience accumulated so far, the lowered ceruloplasmin activity in the sera of exposed rats, the apparently favourable effects of $\mathrm{Zn}$ and $\mathrm{Cu}$ saltenriched diet, as well as the results of the present work, suggest that changes in metal metabolism deserve attention as one of the possible pathogenic links in the development of carbon-disulphide intoxication.

\section{References}

Asanová, T. P. (1971). Pathogenic treatment of occupational carbon-disulphide intoxication (in Russian). In Proceedings of the Congress of the Hungarian Society of Occupational Health, Budapest, pp. 79-83.

Campbell, A. M. G. (1963). Veterinary workers and disseminated sclerosis. Journal of Neurology, Neurosurgery and Psychiatry, 26, 514-515.

Daniel, P., Porter, R. J., Russell, W. Ritchie, Smith, H. V. and Innes, J. R. M. (1947). Diseases of the nervous system occurring among research workers on swayback in lambs. Brain, 70, 50-58.

Djurić, D., Stojadinović, L., Bojovic, V., and Rezman, I. (1968). Chelating effects of carbon disulphide metabolites. II. Determination of zinc and copper in the urine of exposed persons. Medicina del Lavoro, 59, 361-365.

El-Gazzar, E., El-Sadik, Y., and Hussein, M. (1973). Changes in zinc and serum proteins due to carbondisulphide exposure. British Journal of Industrial Medicine, 30, 284-288.

Gadaskina, I. D. and Andreeva, N. B. (1969). Some biochemical shifts occurring in the organisms following carbon disulphide poisoning (in Russian English summary). Gigiena Truda $i$ Professionalnye Zabolevania, 13, no. 4, pp. 28-32. 
Hernberg, S. and Nordman, C-H. (1969). Failure to find increased excretion of zinc or magnesium in humans exposed to carbon disulphide. Medicina del Lavoro, 60, 163-168.

Kocinová, F. and Lukáś, E. (1969). Unpublished data.

Kotas, P., Obrusník, I., Lukáš, E., and Krivánek, M. (1972). Dosage du $\mathrm{Zn}$ et $\mathrm{Cu}$ dans les nerfs periphériques des rats atteins de neuropathie du sulfure de carbone. Conférence Internationale sur les Tendences Modernes de l'Analyse par Activation. Proceedings. Paris 2-6 Oct., 1972.

Kujalová, V. and Lukáš, E. (1969). Unpublished data.

- (1970). Unpublished data.

Lukáš, E. (1970). Stimulation electromyography in experimental toxicology. (Carbon disulphide neuropathy in rats). Medicina del Lavoro, 61, 302-308.

Mádlo, Z. and Souček, B. (1956). Reaktion des Schwefelkohlenstoffes mit Proteinen. Archiv für Gewerbepathologie und Gewerbehygiene, 14, 554-557.

Můr, J., Zăruba, M., and Charamza, O. (1956). Experimental myelin destruction due to chronic application of Cooper-analytical agents (in Czech). Acta Universitatis Palackianae Olomoucensis, 11, 141-148.
Phillips, P. H. and Hart, E. B. (1935). The effect of organic dietary constituents upon chronic fluorine toxicosis in the rat. Journal of Biological Chemistry, $109,657$.

Scheel, L. D. (1967). Experimental carbon disulphide poisoning in rabbits. Its mechanism and similarities with human case reports. Toxicology of Carbon Disulphide, edited by $\mathrm{H}$. Brieger and J. Teisinger, pp. 107-117. Excerpta Medica Foundation, Amsterdam.

Souček, B. and Mádlo, Z. (1956). Dithiocarbamincarbonsäuren als Abbauprodukte des Schwefelkohlenstoffs. Archiv für Gewerbepathologie und Gewerbehygiene, 14, 511-521.

Received for publication 30 May 1973

Accepted for publication 1 February 1974 